\title{
Role of faith and belief in environmental engagement and action in MENA region
}

\author{
William Avis \\ University of Birmingham
}

19 May 2021

\section{Question}

What evidence tells about the role of faith and belief in environmental engagement and action in MENA region?

\section{Contents}

1. Summary

2. Religion and Environmental Challenges

3. The MENA region and religion

4. Islamic thought and Climate Change

5. Constraints to action

6. References

The K4D helpdesk service provides brief summaries of current research, evidence, and lessons learned. Helpdesk reports are not rigorous or systematic reviews; they are intended to provide an introduction to the most important evidence related to a research question. They draw on a rapid deskbased review of published literature and consultation with subject specialists. 


\section{Summary}

Almost all religions reflect on the creation of the universe, or universes, in different forms and with varying degrees of clarity or detail. Common across most religions is an agreement that "creation" is an act of God and should be treated as such. This rapid literature review collates evidence on the role of faith and belief in environmental engagement and action in MENA region. The review draws on academic and grey literature and finds an expanding evidence base on the relationship between Islam, Islamic thought and climate change. It also identifies emerging examples of green approaches to pilgrimage and the 'greening' of places of worship. Evaluations or assessments of these initiatives are, however, limited and inconclusive and much of the evidence is from a theoretical or philosophical position. Similarly, reflections on the traction of interventions such as the Islamic Declaration on Climate Change are mixed, identifying a lack of traction. The review draws particularly on the work of Skirbekk et al. (2021); Koehrsen (2021) and the UNEP Faith for Earth Initiative.

The evidence base on the connections between religion and climate change is wide ranging, including: social science research into how religious identity figures in attitudes toward climate change; confessional and constructive engagements of religious thought with climate change from various communities and traditions; historical and anthropological analyses of how climate affects religion and religion interprets climate; and theories by which climate change may itself be interpreted as a religious event.

In general, the activities that religious organisations can undertake to further climate change mitigation can be delineated into three categories:

- campaigning publicly to raise greater concern about climate change and lobbying among political decision-makers (e.g., through public statements, media campaigns, and advocacy work),

- materialising change by undertaking socio-technological measures to reduce carbon emissions (e.g., switching energy consumption of religious buildings to renewables),

- disseminating pro-environmental values and worldviews to their religious constituencies and thereby potentially influencing their lifestyles (e.g., through religious school teachings and messages during religious services).

Muslim environmentalists draw upon the Qur'an and Sunna to generate environmental principles, thereby creating ecological interpretations of Islam and a set of Islamic environmental ethics. The main principles referred to are Tawhid and Khalifa. Their role within Islamic environmentalism is interrelated with other important principles: Mizan and Maslahah.

- Tawhid refers to the Oneness of God and is interpreted as relating to Unity of Creation, including humans and nature

- Mizan refers to Balance and is interpreted as relating to Harmony of all parts of Creation

- Khalifa refers to Humans as God's vicegerents and is interpreted as relating to Humans as stewards of God's Creation 
- Maslahah refers to Public interest and is interpreted as relating to Care for future generations

Islam teaches its followers to take care of the Earth. Muslims believe that humans should act as guardians, or khalifah, of the planet, and that they will be held accountable by God for their actions. This concept of stewardship is a powerful one, and was used in the Islamic Declaration on Climate Change to propel change in environmental policy in Muslim countries. In the Quran there are approximately 200 verses concerning the environment.

When discussing faith and action, it is important to distinguish between "Islam" as an abstract religious knowledge system and "Muslims" as individual and collective actors (e.g., organisations) who identify with Islam. These actors may interpret the religious knowledge system in different ways. As this review shows, there is no uniform interpretation of climate change among Muslims. Based on their interpretations of Islam, Muslims have generated different approaches to climate change.

Regional traditions of Islam are likely to inform the interpretations of phenomena related to global warming. Therefore, there is a need for more empirical research on regional differences that considers the Islamic interpretations of Muslims living in the given areas.

\section{Religion and Environmental Challenges}

Almost all religions reflect on the Creation of the universe, or universes, in different forms and with varying degrees of clarity or detail. Common across most religions is an agreement that "creation" is an act of God and should be treated as such (UNEP Faith for Earth Initiative ${ }^{1}$ ). Religious or spiritual values drive individual behaviours for more than $80 \%$ of the global populace and in many countries, spiritual beliefs and religions define cultural values, social inclusion, political engagement and economic prosperity (Inkpen \& Baily, 2020). As a marker of identity that transcends national borders, religion exerts a significant influence on environmentally relevant behaviours. Understanding religion's role in addressing transnational environmental challenges is thus an area of significant interest.

As Skirbekk et al. (2021) comment, the evidence base on the connections between religion and climate change is wide ranging, including: social science research into how religious identity figures in attitudes toward climate change; confessional and constructive engagements of religious thought with climate change from various communities and traditions; historical and anthropological analyses of how climate affects religion and religion interprets climate; and theories by which climate change may itself be interpreted as a religious event (Jenkins et al. 2018). Despite the broad nature of interest, there are few systematic overviews focused specifically on the interface between religion and climate change. It is acknowledged that religion influences many aspects of lifestyle that affect the environment, including (Skirbekk et al. 2021):

- childbearing decisions and the use of contraceptives (and resulting effects on population growth);

\footnotetext{
${ }^{1}$ https://www.unep.org/about-un-environment/faith-earth-initiative/religions-and-environmentalprotection\#: :text=Almost\%20all\%20religions\%20address\%20the,should\%20be\%20treated\%20as\%20such.
} 
- risk behaviours and use of health services (which affect life expectancy);

- whether people see climatic change as human-caused, or related to forces beyond human control;

- consumption patterns, and thereby use of natural resources and emissions of greenhouse gases;

- willingness to take actions to abate environmental degradation.

Religious groups, faith based organisations and religious adherents have been recognised as key players in eradicating poverty, improving people's health, protecting the environment and working toward sustainable development (Skirbekk et al., 2021; Inkpen \& Baily, 2020). Religious or spiritual leaders may play a critical role in propagating an ethical, moral and spiritual commitment to protect the environment and God's Creation. These leaders can become observers, make public commitments, share the story of their commitments and the challenges and joys of keeping them, and invite others to join them. In addition, they can display their sustainable behaviours, serving as role models for their followers and the public (UNEP Faith for Earth Initiative).

Broader reflections on the relationship between religion and climate change have discussed an ongoing "greening" process of religions, meaning that religious traditions over time become more environmentally aware and engaged (Koehrsen, 2021). Others are more sceptical of this, as in the case of Taylor et al. (2016)

Apart from "green" reinterpretations of faith traditions, religious communities have started to undertake environmental activities, such as making public statements, consultations with national and regional governments, recycling or tree-planting projects, and environmental education (Mohamad et al., 2012). For these reasons, commentators have stressed the transformational potentials of religions to facilitate transitions toward more environmentally sustainable societies and to address climate change (Palmer, 2013).

There is also an economic argument for engaging faith-based organisations (FBOs). FBOs are the fourth largest economic power on Earth and thus possess both the resources and infrastructure to drive change. An example of the infrastructural power of religion is provided below, globally there are (UNEP Faith for Earth Initiative):

- 37 million churches

- 4 million mosques

- Millions of temples

- $5 \%$ of total commercial forests - $30 \%$ of which lie in Europe are owned by FBOs

- $10 \%$ of financial institutions are owned by FBOs

\section{Religion and the Human-Environment Nexus}

Religion includes beliefs, worldviews, practices, and institutions that cross borders and time from the level of individuals to multinational movements, but the mechanisms through which religion works can differ across contexts (Haluza-DeLay, 2014). These mechanisms can work indirectly on environmental outcomes, such as through religion's influence on education, income, reproductive behaviour and consumption patterns. 
Religious groups may encourage pro-environmental behaviours for several reasons, including those based on theologies of stewardship of Creation or dominion over the Earth. Religious convictions may influence both perceptions and behaviour relating to environmental challenges (Newman \& Fernandes 2016). People who are guided by normative goals, which in turn can be influenced by religious affiliation, are more likely to acknowledge environmental problems and more inclined to assume responsibility in terms of environmentally-friendly behaviours.

Religious ethics are understood as the moral principles that guide religions and that set the standard for what is and isn't acceptable behavior. These often ae similar across religions. The relationship of these religious ethics with sustainabile behaviours is complex. Results from systematic reviews highlight the role of religion as a distal or background factor of other proximal determinants of environmental behaviour (Orellano et al, 2020).

Importantly, the existing literature on how religion affects environmental behaviour is disproportionally focused on Christianity and the global north with a smaller but emerging literature exploring the issue on a global scale (Skirbekk et al., 2021).

One study (Zemo \& Nigus 2020) using representative data from 91 countries collected from 1989-2014 through the World Values Survey indicate that religion is associated with a greater willingness to pay for environmental protection and fewer conflicts in doing so, and that those who are religious are more likely to donate to ecological causes or demonstrate for the environment. The self-assessed willingness to contribute for environmental protection tends to be more pronounced in the low-income country categories (Zemo \& Nigus 2020).

Religious authorities have consistently made statements on climate change. The World Council of Churches had a Climate Change Program before the Intergovernmental Panel on Climate Change (IPCC) was instituted in 1988. The Dalai Lama made his first speech on climate change in 1990. Most formal statements affirm the universal moral significance of climate change as seen by the light of the practices and beliefs of a particular religious tradition. However, some seek to contest its significance or to shift global climate discourse.

Commonly religious groups, particularly when followers are given freedom, make faith-based arguments about the environment and climate change, including giving human-caused climate change arguments. Almost every faith tradition speaks about the importance of taking care of Creation as a sacred duty. A detailed collection of different religious groups views on environmental challenges and climate change is provided in (Grim 2019 - see also section 3 "The MENA region and religion", for a general overview). Overall, the activities that religious organisations can undertake to further climate change mitigation can be delineated into three categories (Koehrsen, 2018):

- campaigning publicly to raise greater concern about climate change and lobbying among political decision-makers (e.g., through public statements, media campaigns, and advocacy work),

- materialising change by undertaking socio-technological measures to reduce carbon emissions (e.g., switching energy consumption of religious buildings to renewables), 
- disseminating pro-environmental values and worldviews to their religious constituencies and thereby potentially influencing their lifestyles (e.g., through religious school teachings and messages during religious services).

In what follows, the report provides a more detailed overview of potential areas for intervention where religious groups could support efforts to address climate change (Skirbekk et al., 2021; Koehrsen, 2021; Inkpen \& Baily, 2020; UNEP Faith for Earth Initiative):

Land holdings: Faith Based Organisations (FBOs) own or control $8 \%$ of the habitable land surface of Earth and $5 \%$ of all commercial forests. With a portfolio including these substantial resources, the potential aggregate impact on global conservation is immense.

Place based knowledge: Many faith communities consider themselves rooted in particular locations. Traditional knowledge of these areas can support environmental stewardship. In Israel, the Book of Job describes numerous species and has been used in nature restoration efforts. Japanese Shinto monks have recorded changing ice patterns since 1443 and hold a key to understanding climate change. Indigenous peoples have often relied on traditional knowledge to manage land, including cultivating and preserving native species, maintaining balance in ecosystems, and sustainably harvesting natural medicines and other resources.

Religion and Environmental Protection: Willingness to make the institutional changes necessary to mitigate climate change can be influenced by religious views. Perception of and responses to environmental risks may differ depending on systems both in terms of consumption and production patterns, and in terms of a sense of agency related to the ability to anticipate and protect oneself from natural hazards. The relation of religion to protecting nature can be problematic for some: the sacred aspect of nature could preclude environmental action or lead to the denial of climate change (Sachdeva, 2016). Religion can also determine adaption to climate change. Acceptance of carbon capture storage for Muslims can be problematic due to teachings on stewardship, harmony and the intrinsic value of nature.

Polity and Willingness to Pay: Differences in the religious affiliation of those who are exposed to adverse environmental changes versus the religious affiliation of those who contribute more to such changes may influence the ability to implement effective policies to reduce emissions and to adapt to the implications of climate change.

Religion and Reproductive and Cultural Outcomes: Cultural and religious convictions can influence individuals' lifestyles and consumption behaviours, and willingness to change these (Adger et al., 2013).

Interactions with Fertility and Population Growth: Fertility is the primary driver of population growth, and rapid population growth has been linked to a number of environmental concerns. Religion can be an important driver of family formation, marriage and childbearing patterns. For instance, religion is found to substantially affect fertility, and more religious individuals tend to exhibit higher fertility.

Renewable energy in houses of workshop: Many FBOs have switched facilities to renewable energy. FBOs are important partners in bringing renewable energy to scale. The Moroccan Government in collaboration with GIZ has created a Green Mosque program aimed at promoting the dissemination of technologies for energy efficiency and renewable energies and to create jobs (see Box 1). 
Advocates for an energy transition: Significant investments and donations from FBOs are propelling the development of on-grid and distributed renewables, including geothermal, biomass, wind, and solar energy. Some of this funding is reinvestment that has been facilitated by FBOs divesting from fossil fuels. Additionally, FBOs have been actively lobbying legislatures and utilities to make renewable energy more widely available.

Divestment: Since 2012, the fossil fuel divestment movement has mobilised more than $\$ 14$ trillion in commitments from nearly 1,200 organisations, governments, businesses, colleges and non-profits. Faith communities make up 30\% of divestment pledges, the largest share of any category. Divestment takes a variety of forms:

- Full Divestment Commitment - organisation has committed to fully divest from fossil fuels by a target date (e.g. 5 years)

- Partial Divestment Commitment - organisation has committed to partially divest in a certain type of fossil fuels (e.g. coal, tar sands, or fracked natural gas)

- Fossil Free - organisation has completed the transition and no longer holds investments in any type of fossil fuel.

- Several hundred FBOs have made full or partial divestment commitments and more than 25 have made the transition to fossil-free.

Reinvestment: In addition to divestment, there is also a need to reinvest in a number of markets and initiatives that will hasten the transition to a low carbon world. Many FBOs have deployed their finances to bolster projects in the developing world that are increasing access to renewable energy. Others have invested in innovative products and materials. One important resource is FaithInvest ${ }^{2}$, an international organisation working with faith communities to ensure their investments achieve the environmental and sustainable development impacts they seek to implement in the world.

\footnotetext{
${ }^{2}$ https://www.faithinvest.org/
} 
Direct Action: Another important strategy involves targeting dirty energy infrastructure and the financial institutions that fund it through organising, protesting, and other forms of direct action.

Box 1: Morocco: Green mosques (Creating jobs by improving energy efficiency and using renewable energy in mosques) (BMZ, 2017)

To combat climate change, Morocco's Government is advocating greater energy efficiency and the use of renewable energies. The country's mosques and their Islamic clerics are helping to make people recognise the benefits of saving energy.

As of 2017, 100 mosques have been upgraded for energy efficiency and more than $40 \%$ of energy costs are being saved. Almost 1,000 mosques have also undergone energy inventories in preparation for upgrades. 262 additional jobs have been created with project support. As pilot projects, the two largest mosques in Marrakech (Moulay Yazid and Koutoubia) and a mosque in the rural locality of Tadmamt have been fitted with LED lighting, and photovoltaic and solar thermal systems. Almost 400 imams, mourchidates and officials in the Ministry of Habous and Islamic Affairs (including 94 women) have taken part in the project's awareness workshops. The participatory process has led to the development of a guideline containing religious arguments for energy efficiency and increased use of renewable energies. With the intensive participation of regional actors in the consultation process, the project has been able to carry out various employment promotion activities in four regions of Morocco. University graduates and staff from engineering firms have been trained to carry out energy audits and subsequently assisted in their search for employment. The project has so far created 117 new jobs and improved the employability of more than 250 individuals.

\section{The MENA region and religion}

There is no standard definition concerning which countries constitute the MENA region. The region is often is assumed to include 21 countries often divided into four sub-groups:

- the Mashreq region (Egypt, Iraq, Jordan, Lebanon, Palestine, Syria),

- the Maghreb region (Algeria, Libya, Morocco and Tunisia),

- the Gulf Cooperation Council Countries (Bahrein, Kuwait, Oman, Qatar, Saudi Arabia and the United Arab Emirates),

- a fourth cluster including Arab Least Developed Countries (Sudan, Yemen).

The countries of Israel, Turkey and Iran are generally considered separately, although Israel and Turkey are sometimes included in the Mashreq region.

As of 2010, there were $341,020,000$ people living in the MENA, and more than nine-in-ten were Muslims (93\%). The next largest religious group is Christians, who comprise roughly $4 \%$ of the region's total population. Jews make up between $1 \%$ and $2 \%$ of the people in the Middle EastNorth Africa region. Hindus, Buddhists, followers of folk or traditional religions, adherents of other religions, and people who do not identify with a religion each make up less than $1 \%$ of the region's population. ${ }^{3}$

\footnotetext{
${ }^{3}$ Pew-Templeton Global Religious Futures Project http://www.globalreligiousfutures.org/regions/middle-east-
} north-africa 
Table 1: \% of MENA Population by Religious Group

\begin{tabular}{|l|l|}
\hline Religion & $\%$ of Population \\
\hline Muslims & $93 \%$ \\
\hline Christians & $4 \%$ \\
\hline Jews & $1-2 \%$ \\
\hline $\begin{array}{l}\text { Other (Hindus, Buddhists, followers of folk or } \\
\text { traditional religions, adherents of other religions, } \\
\text { and people who do not identify with a religion) }\end{array}$ & $1 \%$ \\
\hline
\end{tabular}

Source: Adapted from Pew-Templeton Global Religious Futures Project

http://www.globalreligiousfutures.org/regions/middle-east-north-africa

Whilst this report focuses on the responses of Islamic faith leaders and Muslims in the region to climate related issues, it is important to recognise the diversity of religious belief evident across the MENA region. It is also important to explore the role that the shared challenge of climate change can play in supporting interfaith dialogue and, correspondingly, the role of interfaith action in addressing the issue.

Within each of these religions there is immense diversity. For example, there is much diversity within Muslim-majority countries, and within the global Muslim population as a whole. Several communities follow unique religious practices or separated into a theology, or combine theologies with other religions:

- 'Alawi Shi'ism: a form of Shi'ism, centered on venerating 'Ali. There are many communities in Syria and Turkey.

- The Druze Faith: Based on an Islamic foundation, but incorporating different practices and theology

- The Bahai' Faith: Related to Shi'i Islam, but recognising a prophet who came after Muhammad,.

- Yazidism; Combination of Islam, Zoroastrian and other traditions.

Similarly, Israel includes Not only Jewish groups but also Muslim, Druze or Christian. In general, Jews with European heritage are called Ashkenazi Jews, while Jews from the Middle East are called Sephardic Jews, or Mizrachim.. Core tenets from the Torah are shared by all Jewish communities, but the practices surrounding them vary from community to community.

These facets of diversity show how many minority groups there are, and have been, in the Middle East, and how problematic it can be to generalize about the religious outlook of a country, or even a small area within a country. I 
Islam and Environmentalism: Islam teaches its followers to take care of the Earth. Muslims believe that humans should act as guardians, or khalifah, of the planet, and that they will be held accountable by God for their actions. This concept of stewardship is a powerful one, and was used in the Islamic Declaration on Climate Change to propel change in environmental policy in Muslim countries. In the Quran there are approximately 200 verses concerning the environment. Muslims are taught that "greater indeed than the creation of man is the creation of the heavens and the earth". The Prophet Muhammad (pbuh) also demonstrated kindness, care and general good principles for the treatment of animals. He outlawed killing animals for sport, told people not to overload their camels and donkeys, commanded that slaughtering an animal for food be done with kindness and consideration for the animal's feelings and respect for Allah who gave it life.

- See "Seven Year Plan for Islamic Action on the Environment"4

- See "Islamic Declaration on Climate Change"5

Judaism and Environmentalism: Jewish tradition emphasises many values that are environmentally responsible. Genesis 2:15 emphasises a responsibility to protect the integrity of the environment so that it's diverse species, including humans: "The human being was placed in the Garden of Eden to till it and to tend it." Similarly, Jewish tradition teaches that human domain over nature does not include a license to abuse the environment. The Talmudic concept bal tashchit, "do not destroy," was developed by the rabbis into a universal doctrine that asserted God's ownership of the land. Psalm 24 notes, "The earth is the Lord's and the fullness thereof." From this concept it follows that any act of destruction is an offense against the property of God. Judaism also underscores the moral imperative of protecting the poor and vulnerable: "When one loves righteousness and justice, the earth is full of the loving-kindness of the Eternal" (Psalms 33:5).

- See "A Rabbinic Letter on the Climate Crisis"6

Christianity and Environmentalism: Most Christians believe that God gave human beings a special responsibility within Creation to cultivate it, guard it and use it wisely. This is called stewardship. Man has to work within Creation and to look after it: God took the man and put him in the Garden of Eden to work it and take care of it (Genesis 2:15). Everything that lives and moves about will be food for you. Just as I gave you the green plants, I now give you everything (Genesis 9:3). However, as the Earth belongs to God, humans must respect it and hand it back to God unspoiled: The Earth is the Lord's, and everything in it, the world, and all who live in it (Psalm 24:1). These passages from the Bible show the dominant message is that God is the one who provides for humans and humans should show they are thankful by taking care of what God has given them.

\footnotetext{
${ }^{4}$ http://www.arcworld.org/downloads/muslim-7yp.pdf

${ }^{5}$ https://www.ifees.org.uk/wp-content/uploads/2020/01/climate_declarationmmwb.pdf

${ }^{6}$ https://theshalomcenter.org/civicrm/petition/sign?sid=17
} 
- See "Encyclical Letter" (Laudato $\mathrm{Si})^{7}$

- See "Church of England call for Long-Term Climate Action"8

\section{Interfaith Dialogues on Climate Change}

The shared challenge of climate change can provide a mechanism to bring together faiths to discuss, share teachings and agree common action. The Interfaith Summit on Climate Change 2014 brought together fait leaders from across religions to agree a common statement (See Climate, Faith and Hope: Faith Traditions Together for a Common Future ${ }^{9}$ ).

A number of interfaith statements attempt to identify values shared across traditions that support action on climate change. The 2015 "Interfaith Climate Statement" to the Paris meeting affirmed that all faiths recognised a moral obligation to avoid harm, respect fairness, and care for the vulnerable ${ }^{10}$. That follows closely the 2015 exhortation to climate action from the Parliament of World Religions, "Embracing Our Common Future," which also mentions duties to future generations and respect for all life ${ }^{11}$.

\section{Environmental Challenges in the MENA Region}

Despite heterogeneity in terms of geography, natural resources, political and social structures, and income levels, MENA countries experience common, trans-boundary, environmental challenges. MENA is considered one of the region's most vulnerable to the impacts of climate change (IPCC, 2013). Environmental stresses - water and arable land scarcity in particular have been an important feature of the region's history and these stresses are increasing in relation to development patterns. Rising temperatures, heightened rainfall variability and rising sea levels (Hungate and Koch 2015), in addition, increasing population and urban growth rates, will amplify environmental stresses. In turn, oil production, deforestation as well as carbonintensive consumption habits (e.g., car use, air conditioning), indicate strong mitigation potentials in MENA countries (Fachruddin Majeri Mangunjaya et al., 2015).

In response to these challenges, governments of Muslim-majority countries have signed international agreements, and some have started to implement green economy strategies (Vaghefi et al., 2015). Examples Include

- Saudi Arabia: After a long history of climate change scepticism/obstructionism at the UN climate negotiations, Saudi Arabia has begun to diversify its oil-dependent economy and has sought to promote low-carbon transportation technologies.

\footnotetext{
${ }^{7}$ http://www.vatican.va/content/francesco/en/encyclicals/documents/papa-francesco_20150524_enciclicalaudato-si.html

${ }^{8}$ https://unfccc.int/news/church-of-england-issues-strong-call-for-long-term-climate-action

${ }^{9}$ https://www.oikoumene.org/resources/documents/interfaith-statement-on-climate-change

10 The Statement: Climate, Faith and Hope: Faith traditions together for a common future https://interfaithclimate.org/the-statement

${ }^{11}$ https://parliamentofreligions.org/climateaction/history
} 
- The United Arab Emirates is implementing, in Masdar City in Abu Dhabi, a pioneering urban development project, striving to develop a carbon-neutral city (Kaminski, 2019).

At the same time, some commentators have lamented an indifference to environmental issues in Muslim-majority countries related to a stronger prioritisation of other societal issues (e.g., poverty, corruption), a slow pace of change (Ali, 2016), insufficient mitigation strategies (Kaminski, 2019), and a weak enforcement of environmental regulations (Abdelzaher \& Abdelzaher, 2017). However, government policies are not necessarily representative of Muslim populations living in these countries nor of the Muslim organisations acting in these countries.

Environmental engagement in the MENA region is a relatively new field of research (Vincenti, 2015). However, environmental activism has been intensifying in the region during the past few decades. It has been most evident in countries with semi-competitive political systems and long histories of collective action (for example, Lebanon, Tunisia, Egypt). While environmental contestation has also emerged to a lesser degree in authoritarian states considered inhospitable to activism (e.g. the Persian Gulf), routine forms of civic engagement have become almost impossible in war-torn Syria, Yemen, and Libya.

Against this backdrop, commentators have stressed the potentials of Muslim organisations and leaders to promote environmental concern. This includes:

- their ability to reach broad populations in Muslim-majority countries through public messages, Friday prayers, and ethical teachings;

- The presence of religious leaders and organisations on the grassroots level converts them into valuable multipliers for reaching out to local communities;

- Given their high legitimacy, local religious leaders may even become gatekeepers who influence what information the given local community regards as credible;

- In addition, Muslim organisations can use their infrastructures and financial resources to undertake practical environmental projects (e.g., recycling) that become experimentation sites for local communities, thus helping them to learn new, more environmentally friendly practices.

\section{Environmental Engagement in the MENA}

Country context and local dynamics very much shape the drivers and barriers of environmental engagement across the MENA region (for a fuller discussion, see Ormert, 2020)

- Egypt's dependence on the hydrocarbon sector for government revenue and to fulfil its domestic energy demand shapes the attitudes towards energy and environmentalism amongst both the ruling elite and the wider public.

- In Turkey, the deep levels of polarisation along Islamist-secularist lines creates difficulties for environmental NGOs to influence the Government. The majority of environmental organisations are secular, but the Islamist-leaning Government is more willing to engage with Islamist environmental non-governmental organisations (NGOs). Turkey's Islamist parties had acknowledges the environment, although there is also evidence that environmental concern is lacking among most Turkish Muslims (Yildirim, 2016: 219). Historically, Islamist parties in Turkey supported heavy industry. In 1997, Virtue Party called for "sustainable development" and "sustainable tourism" in their party 
platform, while Felicity Party outlines a programme "stress[ing] the importance of the natural environment" and calls for "sustainable development, cooperation with NGOs, and public awareness programs".

- In Tunisia, many of the mobilisations during the 2011 revolution embraced the environmental agenda as a tool of resistance against the political system and environmental activism in Tunisia grew during the transitional phase.

- Lebanon suffers from stark sectarian divisions and environmentalism is seen as a way to transcend political divides. Environmental practice often aims to be a-political and is intertwined with a broader set of goals relating to the production of a new societal order.

- In Morocco, where the Government has invested heavily in renewable energy, environmental activism often involves resistance to renewable energy projects and relates to issues such as resource access, political power, and economic justice. Climate advocacy groups also work with women-led small businesses on implementing sustainable solutions at the grassroots level.

- Libya, compared to other Arab League countries, scores highly on the World Values Survey (2011) on issues including membership rate environmental organisations, participation in environmental demonstrations and giving priority to protecting the environment over economic growth. Nevertheless, civil society in general is very weak as a result of several decades of authoritarian rule and ongoing violence.

- In the Occupied Palestinian Territories (OPTs), environmental issues are intimately related to everyday access to resources, their use and control, but environmental activism has been overshadowed by the Israeli Occupation.

- The Islamic Republic of Iran offers strong evidence of an applied Islamic environmental ethic. The revolutionary Government included environmental protection in its 1979 constitution (Yildirim, 2016: 2019). In 1996, a paper by the Department of the Environment (DOE) stated that 'the religious leaders in Iran have found the principles of environmental conservation compatible with the general guidelines of the holy religion of Islam.' (Yildirim, 2016: 219). Additionally, several NGOs have emerged, including the Green Party of Iran, which, has been very vocal about defending Iran's environment (Yildirim, 2016: 219). In Iran, official as well as public attitudes toward the natural environment appear to be unique in the Muslim world. This may be due to the fact that Iran's Islamist regime has faced significant environmental challenges throughout its term (e.g. excessive pollution, overpopulation, and environmental degradation).

- Saudi Arabia, in 1983, the Saudi Government enlisted several Islamic scholars from the University of Jeddah to create an environmental policy centred on Islam. This saw the hiring of several non-Saudi environmental experts (e.g. Iraqi Mawil Izzi Dien and American Abd-ar Rah-man Llewellyn) to head the Meteorology and Environmental Protection Administration of Saudi Arabia, which is heavily based in Islamic environmentalism (Yildirim, 2016: 219)

- Egypt, Yildirim (2016) suggests that The Muslim Brotherhood's short stint in power (2011-2013) shows that the Islamist party did not ideologically prioritise the environment. Amongst the general population, however, there is some evidence of a link between observance of Islam and environmental attitudes and behaviours. Vincenti's (2015) study on Value-Based Social Movements observes that Egyptian environmental movements can be "inspired or indirectly influenced" by religious beliefs and values of participants. 
Successful environmental movements in several countries have key factors in common. They are able to appeal to a broad social base, link well-defined and seemingly apolitical aims to wider social issues, secure important elite and government allies, and utilise new, old and social media to communicate campaigns to the wider public.

There is evidence that public awareness and knowledge of environmental issues in some countries is weak. In others, citizens are well informed about environmental issues, but these are a lower priority than economic and social concerns (e.g. poverty and unemployment).

\section{Islamic thought and Climate Change}

\section{Qur'an and Sunna}

Muslim environmentalists draw upon the Qur'an and Sunna to generate environmental principles from them, thereby creating ecological interpretations of Islam and a set of Islamic environmental ethics (Abdelzaher et al., 2019). Although different authors tend to name different principles, the main ones refered to are Tawhid and Khalifa (Abdelzaher et al., 2019). Their role within Islamic environmentalism is interrelated with other important principles: Mizan and Maslahah. Table 2 summarises these principles.

Table 2: Important principles

Principle Meaning

\begin{tabular}{|l|l|l|}
\hline Tawhid & Oneness of God & $\begin{array}{l}\text { Unity of Creation, including humans and } \\
\text { nature }\end{array}$ \\
\hline Mizan & Balance & Harmony of all parts of Creation \\
\hline Khalifa & $\begin{array}{l}\text { Humans as God's } \\
\text { vicegerents }\end{array}$ & Humans as stewards of God's Creation \\
\hline Maslahah & Public interest & Care for future generations \\
\hline
\end{tabular}

Source: Koehrsen (2021, p. 4), https://onlinelibrary.wiley.com/doi/epdf/10.1002/wcc.702, licensed under Attribution-NonCommercial-NoDerivatives 4.0 International (CC BY-NC-ND 4.0)

Tawhid refers to the oneness of God, as expressed in the first words in the profession of faith: "There is no God but God." Everything comes from this one source of life and is connected to it, including nature. Muslim environmentalists interpret this principle as clarifying the unity of all Creation to which humans belong. Muslim environmentalists frequently connect this principle to Mizan, meaning balance and describing the universe as harmonious. Every detail of Creation has been created to stand in perfect relationship to the other parts of Creation. This principle indicates the interconnectedness of ecosystems. Applied to climate change, it helps to explain global warming as greenhouse gases impacting the balance of the interconnected Creation. 
Khalifa is the often considered the most important theme regarding Islam and ecology. It refers to the role of humans as vicegerents of God on Earth. Muslim environmentalists interpret this role as stewards of God's Creation: God afforded humans with trusteeship over Creation. It is their responsibility to take care of nature. Therefore, caring for nature means serving God. Being stewards of God's Creation, humans have to carefully manage natural resources (e.g., water) as different verses in the Qur'an warn against their overexploitation and wastage. From this viewpoint, climate change appears to be a failure of the assigned trusteeship.

Another frequent principle is Maslahah: the concept of public interest. It pursues a "sustainable achievement of good, welfare, advantages, and benefits of creatures" and prioritises the public welfare over individual, private interests. Relating it to the threat of climate change, this principle implies to think and act globally and care for future generations. As such, Muslim thinkers discuss the obligation to preserve resources and care for future humans.

Public statements on climate change reflect the aforementioned interpretations by Muslim environmentalists. An example is the "Islamic Declaration on Global Climate Change" (International Islamic Climate Change Symposium, 2015) that draws on the Islamic principles (e.g., Khalifa, Mizan) and combines them with scientific insights on global warming. The Declaration illustrates that Islamic environmentalism provides interpretations applicable to climate change. Nevertheless, Muslims may also draw on other interpretations and, thereby, come to other conclusions about climate change, as the following section will show.

\section{Islam, Muslims and the Environment}

As noted by Koehrsen (2021), it is important to distinguish between "Islam" as an abstract religious knowledge system and "Muslims" as individual and collective actors (e.g., organisations) who identify with Islam. These actors may interpret the religious knowledge system in different ways. As this review shows, there is no uniform interpretation of climate change among Muslims. Based on their interpretations of Islam, Muslims have generated different approaches to climate change.

Whilst a growing body of research stresses the importance of religion in understanding and addressing climate change. However, so far, little is known about the relationship between Muslim communities and climate change. Globally, Muslims constitute the second largest faith group, and there is a strong concentration of Muslims in regions that are particularly affected by global warming e.g. the MENA region.

A small section of Muslim environmentalists engage in public campaigning to raise greater concern about climate change, seeks to reduce carbon emissions through socio-technological transition efforts, and disseminates pro-environmental interpretations of Islam (Koehrsen, 2021). However, it remains unclear to what extent these activities generate broader changes in the daily activities of Muslim communities and organisations. Contributions to this research field are often theoretical and stress theological and normative aspects of Islam. Empirical studies have particularly addressed Indonesia and the United Kingdom, whereas knowledge about Muslim climate activism in other world regions is fragmented (Koehrsen, 2021).

Despite this paucity of knowledge, there is growing interest in the role Islamic ethics might play mobilising environmental action (Abdelzaher et al., 2019;). 


\section{Perceptions of climate change among Muslims}

Survey data indicate that the majority of Muslims regard climate change as an important societal challenge. A study conducted by Skirbekk and Pędziwiatr (Skirbekk \& Pędziwiatr, 2018) provides an overview of these surveys. Moreover, it includes the Muslim Leaders Survey undertaken by these two scholars. This survey was carried out in 2018 with 150 Muslim leaders from North Africa, the Middle East, the European Union, the United States, Asia, and the post-Soviet region. Of the interviewed Muslim leaders, $48 \%$ state that climate change is already substantially harming people, while $32 \%$ of the respondents believe that harm will begin in the coming 10 25 years. Considering the most worrying consequences of climate change, $44 \%$ of the interviewed leaders attribute high importance to severe droughts, floods, and more frequent hurricanes; $43 \%$ to a rise of temperatures; and $35 \%$ to growing poverty in developing countries. Skirbekk's and Pędziwiatr's calculations based on the Global Attitudes Survey undertaken by Pew Research in 2015 (Pew Research Centre, 2015) arrived at similar results, showing that $51 \%$ of its Muslim respondents perceive climate change as a very serious problem.

Apart from regional differences regarding the concern about climate change, differences also become apparent in the ways in which Muslims interpret climate change. Research drawing on case studies and smaller interview samples shows that interpretations can be broadly summarised into three types (Table 3). These categories are not necessarily mutually exclusive given that Muslims may also regard human and spiritual causes as jointly producing climate change.

Table 3: Interpretations of climate change among Muslims

$\begin{array}{lll}\begin{array}{l}\text { Interpretation } \\ \text { type }\end{array} & \text { Interpretation of climate change } & \begin{array}{l}\text { For example, visible } \\ \text { among... }\end{array}\end{array}$

\begin{tabular}{|l|l|l|}
\hline Human causes & $\begin{array}{l}\text { Outcome of economic system and western } \\
\text { lifestyles }\end{array}$ & $\begin{array}{l}\text { Muslim leaders and } \\
\text { scholars }\end{array}$ \\
\hline Spiritual causes & $\begin{array}{l}\text { God's punishment for immoral behavior or } \\
\text { fulfilment of end-of-times prophecy }\end{array}$ & $\begin{array}{l}\text { Local populations in Sub- } \\
\text { Saharan Africa }\end{array}$ \\
\hline Skepticism & $\begin{array}{l}\text { Western invention to weaken development of } \\
\text { Muslim world }\end{array}$ & $\begin{array}{l}\text { Political Islamists, farmers } \\
\text { in Bangladesh }\end{array}$ \\
\hline
\end{tabular}

Source: Koehrsen (2021, p.5), https://onlinelibrary.wiley.com/doi/10.1002/wcc.702, licensed under AttributionNonCommercial-NoDerivatives 4.0 International (CC BY-NC-ND 4.0)

Overall, the different interpretations illustrate that there is no unified perception of climate change among Muslims. The given practice and understanding of Islam is embedded in a regional sociohistorical context. Regional Islamic traditions have developed in the course of history and provide frames through which Muslims can interpret environmental challenges. Yet, traditions may also change over time. As such, the presence of "greening" tendencies among Islamic scholars and clergy may influence Muslims' concern about climate change in a given region (Koehrsen, 2021). 


\section{Initiatives}

"Unity of universe": Islamic environmentalism has evolved from the 1960s onward. An original point of reference is a series of lectures by the Iranian-born Muslim philosopher Seyyed Hossein Nasr published in 1968. Drawing on Sufism and the concept of the unity of universe, he stresses the connections between environmental degradation and the spiritual and moral crisis of the modern world (Nasr, 1968).

Islamic environmentalism in the 1980s: The field of Islamic environmentalism has expanded further from the 1980s on with the works of contemporary figures in Islamic environmentalism such as Mawil Izzi Dien (see footnote ${ }^{12}$ ) and Fazlun Khalid (see footnote ${ }^{13}$ ). Interestingly, the literature on Islamic environmentalism does not refer to the aforementioned sectarian boundaries but rather tends to highlight the unifying function of environmentalism: Engaged Muslims from different branches of Islam can identify with environmentalism, thereby creating an imagined community that struggles for a joint environmental cause. The diasporic background of many Muslim environmentalists and their focus on current societal challenges rather than historical sectarian struggles appears to facilitate such a unification.

Islamic Principles for the Conservation of the Natural Environment: Muslim organisations and leaders have undertaken public campaigning activities, launching public statements and advocating for climate policy among governments. An early example of such a public statement is "Islamic Principles for the Conservation of the Natural Environment", ${ }^{14}$ compiled by scholars from Jeddah University in Saudi Arabia (Ba Kader et al., 1983). This document pronounced environmental policy centred on Islamic principles and became an influential basis for the development of policies in several Muslim states (e.g., Saudi Arabia, Iran) (Kaminski, 2019; Yildirim, 2016). This statement is as follows:

"Protection, conservation and development of the environment and natural resources is a mandatory religious duty to which every Muslim should be committed. This commitment emanates from the individual's responsibility before God to protect himself and his community. It is also a common social duty which rulers, administrative and municipal agencies and organisations undertake in accordance with the responsibilities assigned to them. (...) The primary duty of the ruler and his assistants, whether they are administrative, municipal or judicial authorities, is to do their best to realise the interests of individuals for the betterment of life and society as a whole. This also includes protection, conservation and development of the environment and natural resources." (Ba Kader et al., 1983, pp. 20-21).

Seven Year Plan for Islamic Action on the Environment: In 2008, 22 participants from Islamic non-governmental organisations, academic, Government and Muslim environmental groups from 14 countries developed a 'Seven Year Plan for Islamic Action on the Environment' (M7YAP) ${ }^{15}$.

\footnotetext{
12 https://www.cilecenter.org/about-us/our-team/dr-mawil-izzi-dien

${ }^{13}$ https://www.ifees.org.uk/about/the-founder/

${ }^{14}$ https://portals.iucn.org/library/sites/library/files/documents/EPLP-020.pdf

${ }^{15}$ http://www.arcworld.org/downloads/muslim-7yp.pdf
} 
This was part of an initiative by the Earth-Mates Dialogue Centre (EMDC) and the Alliance of Religions and Conservation (ARC) to "to harness the teachings, values and ethical law of the Islamic faith in the service of humanity, in order to meet one of the most serious challenges in the contemporary world" (ARC, 2008).

Islamic Declaration of Climate Change: The Islamic Declaration on Global Climate Change was the result of a collaboration between Muslim specialists consisting of academics, environmentalists, organisations and individuals culminating in a substantive document (Islamic Relief Worldwide, the Islamic Foundation for Ecology \& Environmental Sciences (IFEES), and Green Faith).

Institutional partners such as the Islamic Scientific Educational and Cultural Organization and The Organization of the Islamic Conference (largest intergovernmental organisation of Muslim States) supported the Declaration. The Declaration integrates scientific and religious knowledge (e.g., Qur'anic verses and principles such as Tawhid, Mizan, and Khalifa) and makes different "calls" to political leaders at the United Nations Climate Change Conference, faith leaders, businesses, organisations, and believers. These "calls" also include the "oil-producing states," requesting them to "(I)ead the way in phasing out their greenhouse gas emissions as early as possible and no later than the middle of the century" (International Islamic Climate Change Symposium, 2015, p. 6). Some scholars have suggested that this Declaration may create substantial pressure on countries in the Middle East (Ali, 2016: 174), as well as an impact on Muslim mitigation efforts "if the imams in mosques are committed to reminding the (...) rapidly increasing number of Muslims of their moral responsibilities as taught in the Qur'an and by their revered prophet". However, this Declaration received far less media attention than "Laudato Si," and its impact remains, so far, unclear (Hancock, 2018: 20).

The Declaration included a range of references from Qur'anic verses and Ahadith (sayings and traditions of the Prophet Muhammad), set specific targets for Muslim countries, and called for businesses in Muslim countries to divest from fossil fuels. The Declaration was the initiative of a coalition of civil society organisations working on environmental education in Muslim societies, alongside The Islamic Scientific Educational and Cultural Organisation (ISESCO), The Organisation of the Islamic Conference, and the International Islamic Fiqh Academy based in Saudi Arabia. Ali (2016: 173) notes that "what was notable about the declaration was its willingness to challenge the fossil fuel economy of the Middle East".

The "Islamic Declaration on Climate Change," drafted at the Islamic Conference on Climate Change, holds that although humans are called to the role of caretaker or steward (khalifa) of Earth, corrupt performance of that caretaking role by humans has instead wrought damage and destabilisation. The Islamic Declaration specifically calls on oil-producing states to phase out greenhouse gas emissions and calls on all nations to commit to a zero-emissions strategy.

Both examples above draw on a range of Islamic thought to articulate an argument for action. This includes a wide range of verses in the Qur'an that support the protection of the environment with proponents of sustainability identifying that Islam approaches the environment from a stewardship perspective. The Earth is God's Creation, and humans have been entrusted to preserve it. The responsibility of humanity is to protect and ensure the unity (Tawheed) of God's Creation. It is also important to note that Islam prohibits the excessive consumption of resources (Qur'an 7:31, 6:141, 17:26-27, 40:34) and the Qur'an mentions wasteful consumption (Isrāf) as the thirty-second greatest sin. Key facets, connections and reflection on the environment include: 
"Devote thyself single-mindedly to the Faith, and thus follow the nature designed by Allah, the nature according to which He has fashioned mankind. There is no altering the creation of Allah." (Qur'an 30:30)

"Do not strut arrogantly on the earth. You will never split the earth apart nor will you ever rival the mountains' stature" (Qur'an 17: 37).

"It is Allah who made for you the Earth a place of settlement and the sky a ceiling and formed you and perfected your forms and provided you with good things. That is Allah, your Lord; then blessed is Allah, Lord of the worlds." (Qur'an, 40:64).

Fatwa on illegal wildlife trade: The Indonesian Council of Ulema issued a fatwa (Muslim religious decree) declaring the illegal wildlife trade forbidden under Islamic law. It is the first-ever fatwa issued against illegal wildlife trafficking and resulted out of a partnership between the Alliance of Religions and Conservation and WWF Indonesia. The fatwa requires the country's 200 million Muslims to take an active role in protecting threatened species, including tigers, rhinos, elephants and orangutans. 6 Although not binding under Indonesian law, the fatwa is an effective deterrent in a country that is $87 \%$ Muslim.

\section{Faith and Finance}

Faith-based investing remains a niche within the overall socially responsible investing theme, but involves the idea of using ethics to guide monetary decisions. Faith-based organisations represent a sizeable opportunity for Socially Responsible Investment (SRI) funds and reasonable case for wider impact investment and ethical businesses. Religious investments may be governed by beliefs and religious laws, Islamic financial institutions, for example, ban interest on investment and use the Sharia law of finance including Mudaraba (Profit and loss sharing), Wadiah (safekeeping), Musharaka (joint venture), Murabaha (cost plus), and ljar (leasing). The Islamic financial system places equal emphasis on the ethical, moral, social and religious dimensions to enhance equality and fairness for the good of society as a whole. As Calderone et al. (2019) comment:

- There is a growing consensus that financial inclusion can have a range of benefits, including for climate resilience and adaptation. Financial inclusion rates tend to be low in Muslim-majority countries: more needs to be done to develop financial services and instruments that are tailored to the context.

- In scaling-up Islamic financial services, more effort is needed to identify new tools and complement grant funding with different financing approaches. Greater experimentation in product delivery could help in driving down costs, while further product development could contribute to wider acceptance of Sharia-compliant financial services as instruments of financial inclusion and resilience.

- There is also a need to further develop relationships and partnerships to connect private and public actors, as well as linking Islamic finance players and donors with mainstream climate resilience and disaster risk management. 


\section{Materialisation of climate action}

In terms of materialisation, Muslim organisations have, for instance, undertaken reforestation initiatives (Shehu \& Molyneux-Hodgson, 2014), recycling (Mohamad et al., 2012), and energy efficiency measures (Feder, 2009; Schaefer, 2016); implemented solar panels (Hancock, 2018); and constructed low-carbon eco-mosques (Ahmed, 2019; Azmi \& Kandar, 2019).

\section{Box 2: Khalifa Al Tajer Mosque}

The Khalifa Al Tajer Mosque is the Middle East's first eco-friendly mosque. Positioned in Deira, the mosque is to offer prayer and can house up to 3,500 worshippers. The Khalifa Al Tajer Mosque is made from green building materials, and is skillfully designed to use solar energy to power the lights, which makes use of air conditioners that emit reduced greenhouse gases and boasts thermalinsulation systems for lowering energy consumption.

With regard to value dissemination, Muslim initiatives have sought to diffuse greater concern about climate change and environmental degradation and encourage lifestyle changes among their community members by drawing on educational programs, workshops, information guides, and newsletters (Hancock, 2019). One example is the "Green Hajj Guide", aiming to create greater environmental concern among pilgrims (Fachruddin Majeri Mangunjaya et al., 2015).

\section{Box 3: The Green Guide for Hajj (Alliance of Religions and Conservation, 2011) \\ This is a brief guide about the teachings of Islam concerning the conservation of the environment by those who intend to perform Hajj and Umrah. The Guide also provides recommedations for Governments and Institutions to enable a "Greener Hajj and Umrah".}

\section{Constraints to action}

In the MENA region, and beyond, some of the world's most prominent Islamist groups (e.g. Muslim Brotherhood, Hizbullah, and Hamas) make limited or no mention of the environment in their party programmes. In contrast, the governments of Saudi Arabia, Pakistan, Iran, Turkey, and Egypt (with varying levels of Islamist control of the Government) have, to varying degrees, acknowledged concerns about the environment (Yildirim, 2016: 219):

Ali (2016: 175) notes that "given the vast geographic expanse of Islamic countries from Indonesia to Morocco, there is a wide spectrum of ideas and perspectives, and therefore, it is important to highlight that Muslims, like others engaged in the environmental movement, may have many different ideas influencing their decision to join this global effort." Yildirim (2016) suggests that Islamists have a mixed track record on environmentalism. Globally, some international Islamist organisations have included environmental components in their platforms, and educationoriented Muslim environmental groups have formed in a handful of western countries. But policyoriented environmental groups in the Muslim world are still relatively few, and an Islamic environmental movement has yet to emerge (Özler \& Obach, 2018: 314). 
Islam does not have a unified leadership or centralised organisational structure. Muslims come from a variety of ethnic and religious subgroups that live and understand Islam in different ways (Pew Research centre, 2016). The two most prevalent branches of Islam are Sunni and Shia. The Pew Research Center (2009) has suggested that approximately $87-90 \%$ of Muslims are Sunni and $10-13 \%$ are Shia. Beyond Sunni and Shia Islam, there are smaller branches (e.g., Ahmadiyya, Mahdavia) that do not fall under these two major branches and whose belonging to Islam is sometimes contested.

Efforts to combine Islam and environmentalism and apply it to climate change have also provoked critical comments. The criticism points to the selective reading and reinterpretation of traditional scriptures (Hancock, 2018), suggesting that Muslim (and non-Muslim) environmentalists have taken specific verses from the Qur'an and related them to Western concepts of environmentalism, often without considering their broader context and other, more relevant interpretations. Critics fear that such selective interpretations are unlikely to resonate with broader sections of the global Muslim community as these interpretations do not relate to the prevalent understandings of Islam.

In consequence, there are different opinions regarding the broader impact of Islamic environmentalism. Some have suggested a rising ecological concern among Muslims (Ali, 2016). Moreover, Brockopp states that the green movements in Islam are "not simply faddish responses to the issue of the day but fundamental shifts in the way that Islam is taught and understood" (Brockopp, 2012: 217). Studies also suggest increasing environmentalism among political Islamists, partly describing their use of an environmentalist language as a calculated strategy (Karagiannis, 2015). In contrast, Bagir and Martiam assert that the natural environment does not occupy an important place in Islamic thought due to a stronger focus on other issues such as radicalism, terrorism, democracy, and human rights (Bagir \& Martiam, 2016). From this perspective, Muslim environmentalists remain a rather small minority within the global Muslim community. While a growing number of theoretical contributions unfold the normative potentials of Islam to address environmental problems, little is known about the extent to which these "green" readings affect the perceptions and behaviour of broader Muslim populations with regard to climate change.

Considering five global problems suggested in the World Value Survey, only $8 \%$ of Muslim respondents selected "environmental pollution" as the most important problem, while the majority opted for "people living in poverty and need." At the same time, the percentage of Muslims opting for the environment varies in different countries. While less than $1 \%$ of the Muslim interviewees living in Nigeria and Pakistan regarded environmental pollution as the most pressing problem, this number rises to $22 \%$ for Muslim respondents in Uzbekistan, $17 \%$ in Russia, and $16 \%$ in India. Moreover, comparing different types of environmental pollution, Muslim interviewees tend to attribute higher importance to the pollution of rivers, lakes, and oceans than to global warming. Only in Burkina Faso, Ethiopia, and Jordan did Muslims prioritise global warming over other environmental challenges.

Most literature on Islam, the environment, and climate change is theoretical and focuses on Islamic environmental ethics. While it indicates a growing ecological thought, it is unclear to what extent this "greening" affects broader sections of the global Muslim community. Research suggests that Islamic environmentalism is still a minority phenomenon among Muslims. Future studies may explore different channels through which the "greening" of Islam is expanding in 
various world regions. In particular, Muslim leadership on national and local scales may have an important impact on the presence of environmentalism among local communities. In addition, pioneering benchmark projects (e.g., "green" Mosques) may also help to create greater awareness.

Regional traditions of Islam are likely to inform the interpretations of phenomena related to global warming. Therefore, there is a need for more empirical research on regional differences that considers the Islamic interpretations of Muslims living in the given areas.

\section{References}

Abdelzaher, D., Kotb, A., \& Helfaya, A. (2019). Eco-Islam: Beyond the principles of why and what, and into the principles of how. Journal of Business Ethics, 155, 623643. https://doi.org/10.1007/s10551-017-3518-2

Adger, N. (2013). Cultural Dimensions of Climate Change Impacts and Adaptation. Nature Climate Change 3 (2):112-117. http://dx.doi.org/10.1038/nclimate1666

Ali, S. (2016). Reconciling Islamic Ethics, Fossil Fuel Dependence, and Climate Change in the Middle East. Review of Middle East Studies. Vol. 50, No. 2. https://www.jstor.org/stable/26252247?seq=1

Alliance of Religions and Conservation (2011). The Green Guide for Hajj. http://www.arcworld.org/downloads/green_guide_for_hajj.pdf

BMZ (2017). Morocco: Green mosques. BMZ. https://www.giz.de/en/downloads/giz2017-enutilisation-en-Allemagne.pdf

Brockopp, J. (2012). Introduction to Special Issue: Islam and Ecology: Theology, Law and Practice of Muslim Environmentalism. Worldviews. Vol. 16, No. 3. https://www.jstor.org/stable/43809776

Calderone, M. et al. (2019). Investing in financial inclusion for climate resilience and adaptation. ODI. https://cdn.odi.org/media/documents/12685.pdf

Fachruddin Majeri Mangunjaya et al. (2015). Reviving an Islamic Approach for Environmental Conservation in Indonesia. World Views Environment Culture Religion 16 (3). http://dx.doi.org/10.1163/15685357-01603006

Grim, J. (2019). Routledge Handbook of Religion and Ecology. Routledge

Haluza-DeLay, R. (2014). Religion and climate change: Varieties in viewpoints and practices. Wiley Interdisciplinary Reviews: Climate Change,5(2). 261-279. https://doi.org/10.1002/wcc.268

Hungate B.A. and Koch G.W. (2015). Global Change - Biospheric Impacts and Feedbacks. In Encyclopedia of Atmospheric Science (Second Edition). North. G.R., Pyle J., Zhang F. (eds.). 132-140.

Inkpen, R. \& Baily, B. (2020). Environmental beliefs and their role in environmental behaviours of undergraduate students. Journal of Environmental Studies and Sciences volume 10. https://link.springer.com/content/pdf/10.1007/s13412-019-00570-z.pdf

IPCC (2013). Climate Change 2013. IPCC. https://www.ipcc.ch/site/assets/uploads/2018/03/WG1AR5_SummaryVolume_FINAL.pdf 
Jenkins, W. et al. (2018). Religion and Climate Change. Annual Review of Environment and Resources. Vol. 43:85-108. https://doi.org/10.1146/annurev-environ-102017-025855

Kaminski, J. J. (2019). The OIC and the Paris 2015 Climate Change Agreement: Islam and the Environment. In L. A. Pal \& M. E. Tok (Eds.), Global governance and muslim organizations. Springer.

Karagiannis, E. (2014). When the green gets greener: political Islam's newly-found environmentalism. Small Wars \& Insurgencies. Volume 26 Issue 1. https://doi.org/10.1080/09592318.2014.959768

Koehrsen, J. (2021). Muslims and climate change: How Islam, Muslim organizations, and religious leaders influence climate change perceptions and mitigation activities. WIREs Climate Change. Volume 12, Issue 3. https://doi.org/10.1002/wcc.702

Mohamad, Z. F., Idris, N., \& Mamat, Z. (2012). Role of religious communities in enhancing transition experiments: A localised strategy for sustainable solid waste management in Malaysia. Sustainability Science, 7(2), 237-251. https://doi.org/10.1007/s11625-012-01691

Newman, T. \& Fernandes, R. (2015). A re-assessment of factors associated with environmental concern and behavior using the 2010 General Social Survey. Environmental Education Research. Volume 22. Issue 2. https://doi.org/10.1080/13504622.2014.999227

Orellano, A. et al. (2020). The Influence of Religion on Sustainable Consumption: A Systematic Review and Future Research Agenda. Sustainability. https://www.mdpi.com/2071$1050 / 12 / 19 / 7901 / p d f$

Orrnert, A. (2020). Drivers and barriers to environmental engagement in the MENA region. Helpdesk Report 832. Brighton, UK: Institute of Development Studies. https://opendocs.ids.ac.uk/opendocs/bitstream/handle/20.500.12413/15498/832 Drivers a nd_barriers_of_Environmental_Engagement_in_MENA.pdf?sequence $=1$ \&isAllowed=y

Palmer, M. (2013). The quiet revolutionaries: why the faith-based environmental movement has become the largest civil society movement in the conservation world. Biodiversity, 14(3), 180-182. https://doi.org/10.1080/14888386.2013.826459

Sachdeva, S. (2016). Religious identity, beliefs, and views about climate change. https://www.fs.fed.us/nrs/pubs/jrnl/2016/nrs_2016_sachdeva_003.pdf

Skirbekk, V. et al. (2020). How Religion Influences Our Relationship With the Environment. Columbia Climate School. https://news.climate.columbia.edu/2020/10/15/religioninfluences-relationship-environment/

Skirbekk, V. et al. (2020). Religious Affiliation and Environmental Challenges in the 21st Century. Journal of Religion and Demography. Vol 7, Issue 2. https://brill.com/view/journals/jrd/7/2/article-p238_5.xml

Taylor, B., van Wieren, G., \& Zaleha, B. D. (2016). Lynn White Jr. And the greening-of-religion hypothesis. Conservation Biology, 30(5) 1000-1009. http://www.brontaylor.com/environmental_articles/pdf/Taylor--etalGreeningofReligionHypothesis_Conbio30.5.1000-1009(2016).pdf

UNEP (2019). Environmental Challenges in the MENA Region. UNEP. https://wedocs.unep.org/bitstream/handle/20.500.11822/31645/EC_MENA.pdf?sequence= 1\&isAllowed $=y$ 
UNEP et al. (2020). Faith Action on the UN Sustainable Development Goals: Progress and Outlook. UNEP.

https://wedocs.unep.org/bitstream/handle/20.500.11822/33848/SDGR.pdf?sequence=1\&is Allowed $=\mathrm{y}$

Vaghefi, N. Siwar, C. \& Aziz, S. A. A. G. (2015). Green economy: Issues, approach and challenges in Muslim Countries. Theoretical Econom-ics Letters, 05 (01). http://dx.doi.org/10.4236/tel.2015.51006

Vincenti, D. (2016). Sustainability transitions in Arab-Islamic countries: Egypt as a case study. Agriculture and Agricultural Science Procedia 8. 135 - 140. https://core.ac.uk/download/pdf/82307759.pdf

Yildirim, A. K. (2016). Between anti-Westernism and development: Political Islam and environmentalism. Middle Eastern Studies, 52(2) 215-232. https://doi.org/10.1080/00263206.2015.1124414

Zemo, K. \& Nigus, H. (2020). Does religion promote pro-environmental behaviour? A crosscountry investigation. Journal of Environmental Economics and Policy Volume 10. Issue 1. https://doi.org/10.1080/21606544.2020.1796820

\section{Key websites}

- UNEP Faith for Earth Initiative: https://www.unep.org/about-un-environment/faith-earthinitiative

- The Parliament of the World's Religions: https://parliamentofreligions.org/projecthome/climate-commitments-project

- United Religions Initiative: https://www.uri.org/who-we-are/cooperation-circles

\section{Suggested citation}

Avis, W. (2021). Role of faith and belief in environmental engagement and action in MENA region. K4D Helpdesk Report No. 1005 . Institute of Development Studies. DOI: 10.19088/K4D.2021.086

\section{About this report}

This report is based on seven days of desk-based research. The K4D research helpdesk provides rapid syntheses of a selection of recent relevant literature and international expert thinking in response to specific questions relating to international development. For any enquiries, contact helpdesk@k4d.info.

K4D services are provided by a consortium of leading organisations working in international development, led by the Institute of Development Studies (IDS), with the Education Development Trust, Itad, University of Leeds Nuffield Centre for International Health and Development, Liverpool School of Tropical Medicine (LSTM), University of Birmingham International Development Department (IDD) and the University of Manchester Humanitarian and Conflict Response Institute (HCRI).

This report was prepared for the UK Government's Foreign, Commonwealth \& Development Office (FCDO) and its partners in support of pro-poor programmes. Except where otherwise stated, it is licensed for non-commercial purposes under the terms of the Open Government Licence v3.0. K4D cannot be held responsible for errors or any consequences arising from the use of information contained in this report. Any views and opinions expressed do not necessarily reflect those of FCDO, K4D or any other contributing organisation.

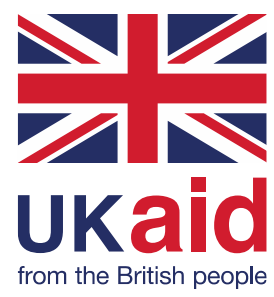

(C) Crown copyright 2021. 